\title{
Addition of Active Dry Yeast Could Enhance Feed Intake and Rumen Bacterial Population While Reducing Protozoa and Methanogen Population in Beef Cattle
}

\author{
Kampanat Phesatcha ${ }^{1, *(\mathbb{D})}$, Krittika Chunwijitra ${ }^{2}$, Burarat Phesatcha ${ }^{3} \mathbb{D}$, Metha Wanapat 4 and \\ Anusorn Cherdthong $4, *$ (D) \\ 1 Department of Animal Science, Faculty of Agriculture and Technology, Nakhon Phanom University, \\ Nakhon Phanom 48000, Thailand \\ 2 Department of Food Technology, Faculty of Agriculture and Technology, Nakhon Phanom University, \\ Nakhon Phanom 48000, Thailand; krittika@npu.ac.th \\ 3 Department of Agricultural Technology and Environment, Faculty of Sciences and Liberal Arts, \\ Rajamangala University of Technology Isan, Nakhon Ratchasima 30000, Thailand; Burarat_kat@hotmail.co.th \\ 4 Tropical Feed Resources Research and Development Center (TROFREC), Department of Animal Science, \\ Faculty of Agriculture, Khon Kaen University, Khon Kaen 40002, Thailand; metha@kku.ac.th \\ * Correspondence: kampanatmon@gmail.com (K.P.); anusornc@kku.ac.th (A.C.); Tel.: +66-4320-2362 (A.C.)
}

\section{check for}

updates

Citation: Phesatcha, K.; Chunwijitra, K.; Phesatcha, B.; Wanapat, M.; Cherdthong, A. Addition of Active Dry Yeast Could Enhance Feed Intake and Rumen Bacterial Population While Reducing Protozoa and Methanogen Population in Beef Cattle. Fermentation 2021, 7, 172 https://doi.org/10.3390/

fermentation7030172

Academic Editor: Ronnie G. Willaert

Received: 11 August 2021

Accepted: 28 August 2021

Published: 30 August 2021

Publisher's Note: MDPI stays neutral with regard to jurisdictional claims in published maps and institutional affiliations.

Copyright: (c) 2021 by the authors. Licensee MDPI, Basel, Switzerland. This article is an open access article distributed under the terms and conditions of the Creative Commons Attribution (CC BY) license (https:/ / creativecommons.org/licenses/by/ $4.0 /)$.

\begin{abstract}
Urea-lime-treated rice straw fed to Thai native beef cattle was supplemented with dry yeast (DY) (Saccharomyces cerevisiae) to assess total feed intake, nutrient digestibility, rumen microorganisms, and methane $\left(\mathrm{CH}_{4}\right)$ production. Sixteen Thai native beef cattle at $115 \pm 10 \mathrm{~kg}$ live weight were divided into four groups that received DY supplementation at $0,1,2$, and $3 \mathrm{~g} / \mathrm{hd} / \mathrm{d}$ using a randomized completely block design. All animals were fed concentrate mixture at $0.5 \%$ of body weight, with urea-lime-treated rice straw fed ad libitum. Supplementation with DY enhanced total feed intake and digestibility of neutral detergent fiber and acid detergent fiber $(p<0.05)$, but dry matter, organic matter and crude protein were similar among treatments $(p>0.05)$. Total volatile fatty acid (VFA) and propionic acid (C3) increased $(p<0.05)$ with $3 \mathrm{~g} / \mathrm{hd} / \mathrm{d}$ DY supplementation, while acetic acid (C2) and butyric acid (C4) decreased. Protozoal population and $\mathrm{CH}_{4}$ production in the rumen decreased as DY increased $(p<0.05)$. Populations of F. succinogenes and R. flavefaciens increased $(p<0.05)$, whereas methanogen population decreased with DY addition at $3 \mathrm{~g} / \mathrm{hd} / \mathrm{d}$, while $R$. albus was stable $(p>0.05)$ throughout the treatments. Thus, addition of DY to cattle feed increased feed intake, rumen fermentation, and cellulolytic bacterial populations.
\end{abstract}

Keywords: beef cattle; digestibility; ruminal fermentation; yeast

\section{Introduction}

To develop more effective ruminant production systems, ruminants must have a high fermentation capacity. The ability of the microbial ecology to digest organic substances into milk and meat precursors is required for increased production [1]. Many feed additives, such as direct-fed microorganisms, are employed to promote livestock productivity. Yeastderived products, such as Saccharomyces cerevisiae, stand out in this group because they are beneficial to animal health and ruminal enhancer [2]. In the rumen, yeast can utilize the remaining dissolved oxygen, sparing anaerobic microbes from the damaging effects of oxygen. Yeasts can increase rumen maturity and regulate ruminal $\mathrm{pH}$ by competing with lactic generating bacteria, minimizing the danger of acidosis [3]. Yeast products lower rumen $\mathrm{pH}$ by encouraging microorganisms that convert lactate into short-chain fatty acids [4]. Yeast improves cattle feed digestion and metabolism in a variety of ways, including increasing nutritional digestibility, optimizing volatile fatty acid proportions, decreasing ammonianitrogen, lowering $\mathrm{pH}$ fluctuation, and stimulating microbial communities in the rumen [5]. Furthermore, yeast provides several growth factors, pro-vitamins, and other stimulants to 
rumen microbes while decreasing rumen redox potential and stimulating the growth of ruminal bacteria, primarily cellulolytic bacteria, which enhance fiber degradation [6]. Moreover, yeast enhanced total volatile fatty acids (VFAs) while decreasing acetate proportion. Supplementation of yeast can help cellulolytic bacteria and increase the digestibility of Nellore cattle [7]. This could be due to increasing cellulolytic and lactate-utilizing bacterial populations modifying lactate-to-propionate fermentative pathways [8]. Feed intake, milk yield, weight gain, digestibility of nutrients, cellulolytic bacteria numbers, and volatile fatty acid patterns have all been shown to improve with yeast supplementation in the ruminant diet $[9,10]$. Furthermore, there is a limitation of data because only a few researchers have studied the rumen microorganism and methane emission in cattle fed urea-lime-treated rice straw. The aim of this study was to study supplementation with Saccharomyces cerevisiae on feed intake, nutritional digestibility, rumen fermentation, rumen microorganism, and methane production in Thai native beef calves fed urea-lime-treated rice straw as a basal roughage.

\section{Materials and Methods}

The study design and plan strictly followed the norms of the Animal Ethics Committee of Nakhon Phanom University, Mueang Nakhon Phanom, Thailand (permission No. AENPU A2/2560). This study primarily involved laboratory analysis of ruminant feeds, for which permission to collect rumen fluid from animals was granted in accordance with the Thailand Ethics of Animal Experimentation of the National Research Council.

\subsection{Animals, Feed, and Experimental Design}

Sixteen Thai native beef cattle with $115 \pm 10 \mathrm{~kg}$ live weight were blocked into four groups to receive active Saccharomyces cerevisiae (dry form) supplementation at 0, 1, 2, and $3 \mathrm{~g} / \mathrm{hd} /$ day. The yeast strain S. cerevisiae in this study was obtained from the Renu Nakhon district, Nakhon Phanom Province, Thailand. All animals received a concentrated mixture at $0.5 \%$ body weight, while urea-lime-treated rice straw, water, and mineral blocks were available ad libitum.

Ingredient compositions of concentrate mixture and nutrient composition are presented in Table 1 . The rice straw-treated urea-calcium hydroxide was made by adding $2 \mathrm{~kg}$ of urea and $2 \mathrm{~kg}$ of $\mathrm{Ca}(\mathrm{OH})_{2}$ in $100 \mathrm{~L}$ to $100 \mathrm{~kg}$ of rice straw. The quantity of urea and calcium hydroxide solution was sprayed onto rice straw bales and then covered with a sheet of plastic for at least 10 days before feeding to the beef cattle [11].

Table 1. Compositions of concentrate mixtures and urea-calcium hydroxide-treated rice straw.

\begin{tabular}{|c|c|c|}
\hline Items & Concentrate & Urea-Calcium Hydroxide-Treated Rice Straw \\
\hline \multicolumn{3}{|c|}{ Concentrate ingredients, $\%$ dry matter basis } \\
\hline Cassava chip & 63.5 & \\
\hline Coconut meal & 10.5 & \\
\hline Palm kernel meal & 7.5 & \\
\hline Rice bran & 11.0 & \\
\hline Urea & 3.0 & \\
\hline Molasses & 2.0 & \\
\hline Mineral mixture & 1.0 & \\
\hline Salt & 1.0 & \\
\hline Sulfur & 0.5 & \\
\hline \multicolumn{3}{|l|}{ Chemical composition } \\
\hline Dry matter, $\%$ & 89.7 & 50.7 \\
\hline \multicolumn{3}{|r|}{$\%$ of dry matter } \\
\hline Organic matter & 94.6 & 90.1 \\
\hline Ash & 5.4 & 9.9 \\
\hline Crude protein & 14.0 & 4.3 \\
\hline Neutral detergent fiber & 25.6 & 70.2 \\
\hline Acid detergent fiber & 15.8 & 48.7 \\
\hline Total digestible nutrients (TDN) * & 79.8 & 50.4 \\
\hline
\end{tabular}

* Calculated value $\% \mathrm{TDN}=[\%$ digestible $\mathrm{CP}+$ Crude fiber $(\mathrm{CF})+$ Nitrogen free extract $(\mathrm{NFE})+(2.25 \times \%$ Digestible Ether extract $(\mathrm{EE})]$. 
The animals were dewormed and given a 14-day acclimation period prior to the experiment. The feeding trial lasted 90 days, with the digestibility test taking place in the final week. The individual feed was made and fed to the cattle in the morning and evening. To measure daily feed intake, the amount of feed supplied and denied was recorded every day, and to determine weight change, weighing was performed every two weeks before feeding time.

\subsection{Samples Collection and Chemical Analyses of Samples}

Representative feed, fecal, and urine samples were collected throughout the last 7 days, weighed, and oven-dried at $60{ }^{\circ} \mathrm{C}$ for $48 \mathrm{~h}$. The composite samples were dried at $60{ }^{\circ} \mathrm{C}$ before being processed ( $1 \mathrm{~mm}$ screen using Cyclotech Mill, Tecator, 1093, Hoganas, Sweden) and tested for DM, CP, and ash [12]. The acid detergent fiber (ADF) was calculated and expressed including residual ash. Determined neutral detergent fiber (NDF) in samples with the addition of alpha-amylase but without sodium sulfite, and the findings are given inclusive of residual ash according to Van Soest et al. [13]. Nutrient digestibility was calculated using acid insoluble ash [14], and DM, OM, NDF, and ADF digestibility were determined from the ratio of AIA in feed and feces, and digestibility of nitrogen was determined from ratios of AIA and $\mathrm{N}$ in feed and feces.

On the final day of the trial, rumen fluid and blood samples were collected at 0 and $4 \mathrm{~h}$ following the morning feed. Each time, a stomach tube connected to a vacuum pump was utilized to collect approximately $200 \mathrm{~mL}$ of rumen fluid from the rumen. Rumen fluid $\mathrm{pH}$ and temperature were immediately measured, and $50 \mathrm{~mL}$ of rumen fluid was collected and mixed with $5 \mathrm{~mL}$ of $1 \mathrm{M} \mathrm{H}_{2} \mathrm{SO}_{4}$ to stop microbial activity fermentation before centrifugation at $16,000 \times g$ for $15 \mathrm{~min}$. A total of $20 \mathrm{cc}$ of supernatant was taken and frozen at $-20{ }^{\circ} \mathrm{C}$ before being analyzed in the laboratory for ammonia-nitrogen $\left(\mathrm{NH}_{3}-\mathrm{N}\right)$ using micro-Kjeldahl methods [12].

High Performance Liquid Chromatography was used to examine rumen fluid samples for VFAs (HPLC; Model Water 600; UV detector, Millipore Corp., Milford, MA, USA). Rumen $\mathrm{CH}_{4}$ production was approximated using equation of Moss et al. [15]. VFA proportions are as follows: production of $\mathrm{CH}_{4}=0.45$ (acetate, $\mathrm{C}_{2}$ ) +0.275 (propionate, $\mathrm{C}_{3}$ ) +0.4 (butyrate, $\mathrm{C}_{4}$ ).

The second portion was fixed with $10 \%$ formalin for the determined protozoal population using the direct count microscopic method as described by Galyean [16].

The community DNA was isolated from rumen fluid and digesta. QIAgen DNA Mini Stool Kit columns were used to purify the DNA (QIAGEN, Valencia, California, USA). Realtime PCR was used to determine the relative populations of total bacteria, rumen bacteria for fiber degradation (Ruminococcus albus, Ruminococcus flavefaciens, Butyrivibrio fibrisolvens, and Fibrobacter succinogenes), and methanogen. Total DNA was extracted from the samples using the method described by Stevenson et al. [17]. Extracted DNA was utilized as a template in real-time PCR experiments with specified primers to measure the microbial population of R. albus, and R. flavefaciens [18], B. fibrisolvens [17], F. succinogenes [19], and methanogen [20]. The DNA standards for real-time PCR amplification and detection were determined using a Chromo $4^{\mathrm{TM}}$ system (Bio-Rad, California, USA). The data of microbial population were transferred to $\log 10$ prior to statistical analysis.

At the same time as the rumen fluid was collected, a $10 \mathrm{~mL}$ blood sample was taken from the jugular vein into a tube containing $0.1 \mathrm{~g}$ of ethylenediaminetetraacetic acid (EDTA). All tubes were centrifuged at $3000 \times g$ for 15 min to obtain plasma and then stored at $-20{ }^{\circ} \mathrm{C}$ for further analyses of blood urea nitrogen (BUN) [21].

\subsection{Statistical Methods}

The data were analyzed using the MIXED procedure in SAS software [22]. The mathematical model assumption used was:

$$
Y_{i}=\mu+T_{i}+\beta_{i}+\varepsilon_{i}
$$


where $Y_{i}$ is the dependent variable, $\mu$ is the overall mean, $T_{i}$ is the ith treatment effect (supplementation of Saccharomyces cerevisiae at 0, 1, 2, $3 \mathrm{~g} / \mathrm{hd} /$ day), $\beta \mathrm{i}$ is the ith block effect, and ${ }_{i}$ is the residual error of the ith observation. Differences among means with $p<0.05$ were represented as statistically significant differences. Orthogonal polynomials for diet responses were determined by linear and quadratic effects.

\section{Results}

\subsection{Feed Intake and Digestibility}

DY supplementation enhanced total feed intake of urea-lime-treated rice straw by Thai native beef cattle $(p<0.05)$ but did not alter digestibility DM, OM, or CP $(p>0.05)$. Supplementation at $3 \mathrm{~g} / \mathrm{hd} / \mathrm{d}$ increased digestibility of fiber (NDF, ADF) $(p<0.05$; Table 2).

Table 2. Effect of yeast supplementation on voluntary feed intake and nutrient digestibility in Thai native beef cattle.

\begin{tabular}{|c|c|c|c|c|c|c|c|}
\hline \multirow{2}{*}{ Items } & \multicolumn{4}{|c|}{ Yeast Supplementation (g/day) } & \multirow{2}{*}{ SEM } & \multicolumn{2}{|c|}{ Contrast } \\
\hline & 0 & 1 & 2 & 3 & & Linear & Quadratic \\
\hline \multicolumn{8}{|l|}{ Dry matter intake } \\
\hline \multicolumn{8}{|l|}{ Roughage intake } \\
\hline $\mathrm{kg} /$ day & $1.9^{\mathrm{a}}$ & $2.0^{\mathrm{a}}$ & $2.3^{b}$ & $2.5^{\mathrm{c}}$ & 0.18 & 0.04 & 0.43 \\
\hline $\mathrm{g} / \mathrm{kg} \mathrm{BW} W^{0.75}$ & $65.9^{\mathrm{a}}$ & $66.0^{\mathrm{a}}$ & $68.1^{b}$ & $70.6^{c}$ & 0.76 & 0.04 & 0.52 \\
\hline \multicolumn{8}{|l|}{ Concentrate intake } \\
\hline $\mathrm{kg} /$ day & 0.7 & 0.7 & 0.7 & 0.7 & 0.31 & 0.17 & 0.41 \\
\hline $\mathrm{g} / \mathrm{kg} \mathrm{BW} W^{0.75}$ & 17.8 & 18.9 & 17.7 & 19.0 & 1.67 & 0.15 & 0.32 \\
\hline \multicolumn{8}{|l|}{ Total feed intake } \\
\hline $\mathrm{kg} /$ day & $2.6^{\mathrm{a}}$ & $2.7^{\mathrm{a}}$ & $3.0^{\mathrm{b}}$ & $3.3^{c}$ & 0.09 & 0.04 & 0.05 \\
\hline $\mathrm{g} / \mathrm{kg} \mathrm{BW} W^{0.75}$ & $84.7^{\mathrm{a}}$ & $84.9^{\mathrm{a}}$ & $85.7^{b}$ & $89.6^{c}$ & 1.24 & 0.04 & 0.05 \\
\hline \multicolumn{8}{|l|}{ Nutrient digestibility, \% } \\
\hline Dry matter & 57.5 & 58.9 & 60.2 & 60.0 & 0.17 & 0.14 & 0.47 \\
\hline Organic matter & 62.8 & 62.7 & 62.4 & 63.4 & 0.05 & 0.25 & 0.32 \\
\hline Crude protein & 58.6 & 59.1 & 59.7 & 60.2 & 0.09 & 0.17 & 0.21 \\
\hline Neutral detergent fiber & $50.1^{\mathrm{a}}$ & $51.9^{\mathrm{a}}$ & $53.2^{b}$ & $55.2^{c}$ & 0.08 & 0.03 & 0.04 \\
\hline Acid detergent fiber & $41.4^{\mathrm{a}}$ & $42.3^{a}$ & $44.9^{b}$ & $46.9^{c}$ & 0.06 & 0.02 & 0.03 \\
\hline
\end{tabular}

$\mathrm{a}, \mathrm{b}, \mathrm{c}$ means within a row with different superscripts differ significantly $(p<0.05)$; SEM = standard error of the mean.

\subsection{Rumen Fermentation, and Blood Urea Nitrogen}

Table 3 shows the effect of DY on rumen fermentation and BUN. The ruminal $\mathrm{pH}$ (6.6-6.8) and ruminal temperature $\left(39.0-39.5^{\circ} \mathrm{C}\right)$ remained stable $(p>0.05)$. The concentration of $\mathrm{NH}_{3}-\mathrm{N}$ increased in the DY supplementation groups and was highest at $3 \mathrm{~g} / \mathrm{hd} / \mathrm{d}$ but did not affect the concentration of BUN $(p>0.05)$.

Table 3. Effect of yeast supplementation on fermentation characteristics and blood urea nitrogen in Thai native beef cattle.

\begin{tabular}{|c|c|c|c|c|c|c|c|}
\hline \multirow{2}{*}{ Items } & \multicolumn{4}{|c|}{ Yeast Supplementation (g/day) } & \multirow{2}{*}{ SEM } & \multicolumn{2}{|c|}{ Contrast } \\
\hline & 0 & 1 & 2 & 3 & & Linear & Quadratic \\
\hline Ruminal pH & 6.8 & 6.8 & 6.7 & 6.6 & 0.09 & 0.09 & 0.15 \\
\hline Temperature, ${ }^{\circ} \mathrm{C}$ & 39.5 & 39.0 & 39.4 & 39.5 & 0.22 & 0.34 & 0.46 \\
\hline $\mathrm{NH}_{3}-\mathrm{N}, \mathrm{mg} / \mathrm{dL}$ & $12.1^{\mathrm{a}}$ & $12.9^{\mathrm{a}}$ & $13.3^{b}$ & $15.6^{\mathrm{c}}$ & 0.30 & 0.02 & 0.03 \\
\hline $\mathrm{BUN}, \mathrm{mg} / \mathrm{dL}$ & 9.1 & 9.5 & 10.7 & 11.3 & 0.06 & 0.52 & 0.62 \\
\hline Total VFAs, mmol/L & $90.1^{\mathrm{a}}$ & $92.8^{a}$ & $96.5^{b}$ & $100.3^{c}$ & 0.15 & 0.03 & 0.04 \\
\hline \multicolumn{8}{|l|}{ VFAs, mol/100mol } \\
\hline Acetic acid $\left(C_{2}\right)$ & $68.1^{\mathrm{c}}$ & $66.6^{\mathrm{b}}$ & $66.4^{\mathrm{b}}$ & $64.8^{\mathrm{a}}$ & 0.18 & 0.02 & 0.04 \\
\hline Propionic acid $\left(C_{3}\right)$ & $20.9^{a}$ & $22.6^{b}$ & $24.1^{\mathrm{c}}$ & $26.0^{\mathrm{d}}$ & 0.16 & 0.02 & 0.03 \\
\hline Butyric acid $\left(\mathrm{C}_{4}\right)$ & $11.0^{\mathrm{b}}$ & $10.8^{\mathrm{b}}$ & $9.5^{\mathrm{a}}$ & $9.2^{\mathrm{a}}$ & 0.07 & 0.03 & 0.05 \\
\hline $\mathrm{C}_{2}: \mathrm{C}_{3}$ & $3.3^{c}$ & $2.9^{b}$ & $2.8^{\mathrm{b}}$ & $2.5^{\mathrm{a}}$ & 0.31 & 0.04 & 0.07 \\
\hline $\mathrm{CH}_{4}(\mathrm{mM})$ & $29.3^{c}$ & $28.1^{b}$ & $27.1^{\mathrm{b}}$ & $25.7^{\mathrm{a}}$ & 0.25 & 0.04 & 0.05 \\
\hline
\end{tabular}

$\mathrm{a}, \mathrm{b}, \mathrm{c}, \mathrm{d}$ means within a row with different superscripts differ significantly $(p<0.05)$; $\mathrm{SEM}=$ standard error of the mean; $\mathrm{NH}_{3}-\mathrm{N}=$ ammonianitrogen; $\mathrm{BUN}=$ blood urea nitrogen; VFAs = volatile fatty acids; $\mathrm{CH}_{4}=$ methane production $=0.45\left(\mathrm{C}_{2}\right)-0.275\left(\mathrm{C}_{3}\right)+0.4\left(\mathrm{C}_{4}\right)$ calculated according to Moss et al. [15]. 


\subsection{Volatile Fatty Acid (VFA) Profiles and Methane $\left(\mathrm{CH}_{4}\right)$ Production}

Concentrations of total volatile fatty acid (TVFA) and propionic acid (C3) increased $(p<0.05)$ with DY supplementation, particularly for DY at $3 \mathrm{~g} / \mathrm{hd} / \mathrm{d}$. However, acetic acid (C2) and butyric acid (C4) concentrations, $\mathrm{C} 2$ : $\mathrm{C} 3$ ratio and $\mathrm{CH}_{4}$ production reduced with the addition of DY at $3 \mathrm{~g} / \mathrm{hd} / \mathrm{d}$.

\subsection{Microbial Population}

Protozoal population significantly reduced $(p<0.05)$ with $\mathrm{LY}$ addition at $3 \mathrm{~g} / \mathrm{hd} / \mathrm{d}$. The bacteria, F. succinogenes, B. fibrisolvens and R. flavefaciens increased, whereas the methanogenic population decreased with DY addition at $3 \mathrm{~g} / \mathrm{hd} / \mathrm{d}$. R. albus was stable $(p>0.05)$ throughout all treatments (Table 4$)$.

Table 4. Effect of yeast supplementation on microbial population in Thai native beef cattle.

\begin{tabular}{|c|c|c|c|c|c|c|c|}
\hline \multirow{2}{*}{ Items } & \multicolumn{4}{|c|}{ Yeast Supplementation (g/day) } & \multirow{2}{*}{ SEM } & \multicolumn{2}{|c|}{ Contrast } \\
\hline & 0 & 1 & 2 & 3 & & Linear & Quadratic \\
\hline $\begin{array}{l}\text { Direct count, cell } / \mathrm{mL} \\
\text { Protozoa, } \times 10^{6} \text { cell } / \mathrm{mL} \\
\text { Real-time PCR, } \\
\text { copies } / \mathrm{mL} \text { rumen content }\end{array}$ & $8.1^{\mathrm{d}}$ & $6.9^{c}$ & $5.2^{b}$ & $3.5^{\mathrm{a}}$ & 0.19 & 0.04 & 0.05 \\
\hline F. succinogenes, $\times 10^{6}$ & $3.2^{\mathrm{a}}$ & $3.6^{\mathrm{a}}$ & $4.8^{\mathrm{b}}$ & $5.9^{\mathrm{c}}$ & 0.07 & 0.04 & 0.07 \\
\hline R. flavefaciens, $\times 10^{5}$ & $2.1^{\mathrm{a}}$ & $2.4^{\mathrm{a}}$ & $3.9^{b}$ & $4.8^{\mathrm{c}}$ & 0.31 & 0.04 & 0.06 \\
\hline R. albus, $\times 10^{6}$ & 5.0 & 4.9 & 5.2 & 5.5 & 0.16 & 0.06 & 0.08 \\
\hline B. fibrisolvens, $\times 10^{5}$ & $2.5^{\mathrm{a}}$ & $3.1^{\mathrm{a}}$ & $4.4^{\mathrm{b}}$ & $6.8^{\mathrm{c}}$ & 0.21 & 0.04 & 0.05 \\
\hline Methanogens, $\times 10^{2}$ & $6.6^{\mathrm{a}}$ & $5.8^{\mathrm{a}}$ & $4.7^{\mathrm{b}}$ & $3.4^{\mathrm{c}}$ & 0.09 & 0.04 & 0.05 \\
\hline
\end{tabular}

$\mathrm{a}, \mathrm{b}, \mathrm{c}, \mathrm{d}$ means within a row with different superscripts differ significantly $(p<0.05)$; SEM = standard error of the mean.

\section{Discussion}

\subsection{Feed Intake and Nutrient Digestibility}

Total feed intake increased with DY supplementation, with the highest found at $3 \mathrm{~g} / \mathrm{hd} / \mathrm{d}(p<0.05)$, concurring with Crossland et al. [6], who found that adding yeast to cattle diet increased dry matter intake. Supplementation of DY at $3 \mathrm{~g} / \mathrm{hd} / \mathrm{d}$ also increased fiber digestibility (NDF, ADF) $(p<0.05)$ due to the ability of yeast to scavenge excess oxygen in the rumen, lower the redox potential, and enhance the degradability of NDF and ADF. Yeast provides an ecological setting that encourages the proliferation and activity of microbes, especially cellulolytic bacteria that enhance NDF and ADF breakdown. Guedes et al. [23] discovered that feeding cattle with yeast improved NDF degradation of maize silage. By contrast, Mir and Mir [24] found that supplementing cattle feed with live yeast did not impact DM and NDF degradation in the rumen. Satori et al. [10] stated that the highest total intake and average daily gain were observed in cattle supplemented with yeast at below $6 \mathrm{~g} / \mathrm{d}$.

\subsection{Rumen Ecology and Blood Urea-Nitrogen}

Ruminal $\mathrm{pH}$ and temperature values for all DY supplementations were reported in the optimal range by Phesatcha et al. [11]. In general, rumen $\mathrm{pH}$ stability benefits acid-sensitive cellulolytic bacteria and is extremely beneficial to beef cattle, especially fattening cattle. Monnerat et al. [25] and Ghasemi et al. [26] reported that adding yeast to high concentrate cattle feed did not affect rumen $\mathrm{pH}$.

The $\mathrm{NH}_{3}-\mathrm{N}$ concentration increased with DY supplementation at $3 \mathrm{~g} / \mathrm{hd} / \mathrm{d}$. The concentration of BUN was similar among treatments and ranged between $9.1 \mathrm{and} 11.3 \mathrm{mg} / \mathrm{dl}$, and in the normal range as reported by Wanapat and Pimpa [27]. By contrast, Li et al. [28] found that the addition of yeast to cattle feed decreased BUN. 


\subsection{Ruminal Volatile Fatty Acid (VFA) Profiles and Methane $\left(\mathrm{CH}_{4}\right)$ Production}

In this study, beef calves fed DY had higher total VFA levels and higher C3 levels, while the $\mathrm{C} 2, \mathrm{C} 4$, and $\mathrm{C} 2$ to $\mathrm{C} 3$ ratio were lower than those no supplemented group. This was due to an increase in the lactate-utilizing bacteria Selenomonas ruminantium and Megasphaera elsdenii that convert lactate to $\mathrm{C} 3$, with their growth stimulated by yeast supplementation [10,29]. When compared to the control, yeast supplementation increased total VFA, C3, and valeric acid but decreased C2 and the C2 to C3 ratio [30,31]. Dawson et al. [32] found that for yeast supplements containing in vitro total VFA, the molar proportion of $\mathrm{C} 3$ increased while $\mathrm{C} 2$ decreased. Variable effects of yeast on rumen fermentation efficiency can be attributed to dose, diet type, different yeast strains, animal physiological stage, and feeding systems $[7,33]$.

Major alterations of $\mathrm{CH}_{4}$ in ruminants are produced through propionate fermentation, and $\mathrm{CH}_{4}$ production decreased with yeast supplementation. This result concurred with Phesatcha et al. [11] and Wang et al. [34], who found that $\mathrm{CH}_{4}$ production decreased with yeast supplementation, while Munoz et al. [35] observed that DY supplementation increased $\mathrm{CH}_{4}$ production in lactating dairy cows and Bayat et al. [36] determined that yeast did not influence $\mathrm{CH}_{4}$ emissions. Diverse effects of yeast supplementation on $\mathrm{CH}_{4}$ synthesis were attributed to varying yeast strains, dosages, and diets utilized in the trials [28]. Yeast can be used to minimize $\mathrm{CH}_{4}$ emissions and was shown to lower methane production in the rumen by encouraging acetogens to use more hydrogen in the process of acetate formation by Darabighane et al. [37]. In this study, the methanogen population was reduced with yeast supplementation and was lowest at $3 \mathrm{~g} / \mathrm{hd} / \mathrm{d}$.

The protozoal population was reduced with DY supplementation. Microbial populations studied using real-time PCR revealed that $R$. flavefaciens, B. fibrisolvens, and $F$. succinogenes increased, while methanogen population decreased with yeast supplementation at $3 \mathrm{~g} / \mathrm{hd} / \mathrm{d}$. This result concurred with Sousa et al. [7], who reported that the addition of yeast significantly increased the relative population of $R$. flavefaciens. The addition of DY stimulated the growth of cellulolytic bacterial populations (R. flavefaciens and $F$. succinogenes), while suppressing growth of the lactate-producing bacterium (Streptococcus bovis), thereby improving the consistency of rumen fermentation [38]. Enhanced fiber degradation increased total cellulolytic bacteria in the rumen. Ding et al. [39] found that the addition of yeast increased bacteria, fungi, protozoa, lactate-utilizing bacteria, and rate of fiber decomposition. Growth factors induced by organic acids and vitamins provided by yeast may enhance cellulolytic bacterial and fungal colonization in the rumen. Yeast promoted microbial proliferation, specifically lactic acid-utilizing bacteria, and reduced acidosis [3,9]. Furthermore, as a facultative anaerobe organism, yeast gathers available oxygen on the surface of freshly swallowed meals to sustain metabolic activity, thereby lowering rumen redox potential. Removal of oxygen improves growth conditions for strict anaerobic cellulolytic bacteria, increasing their adherence to fodder particles and shortening the cellulolytic process [33]. Jiang et al. [29] examined the ruminal microbiota of cows fed with different amounts of yeast. They found that the number of Butyrivibrio fibrisolvens, an important hemicellulolytic species, was reduced in cows supplemented with a high dose of yeast. In our study, methane production and methanogen population reduced with yeast supplementation, and the lowest values were found at $3 \mathrm{~g} / \mathrm{hd} / \mathrm{d}$. By contrast, Lu et al. [40] reported that adding yeast at 6 and $12 \mathrm{~g} / \mathrm{d}$ decreased methane production without affecting the number or diversity of methanogens.

\section{Conclusions}

The addition of DY at $3 \mathrm{~g} / \mathrm{hd} / \mathrm{d}$ enhanced total feed intake, rumen fermentation, and total bacteria populations while reducing protozoal population and $\mathrm{CH}_{4}$ production in beef cattle fed with urea-lime-treated rice straw. However, there are certain drawbacks related to the fattening beef cattle influenced by DY addition, which requires further study. 
Author Contributions: Conceptualization, K.P.; methodology, K.P., K.C. and B.P., validation, K.P. and A.C.; formal analysis, K.P., B.P. and K.C.; investigation, K.P.; resources, K.P. and B.P.; data curation, K.P.; manuscript drafting, K.P.; manuscript editing and finalizing, K.P., A.C. and M.W.; visualization, K.P.; supervision, A.C. and M.W.; project administration, K.P.; funding acquisition, K.P.; All authors have read and agreed to the published version of the manuscript.

Funding: The authors express their most sincere gratitude to the Nakhon Phanom University Fund through the middle class researcher scholarships (MR3/2563), the Research Program on the Research and Development of Winged Bean Root Utilization as Ruminant Feed; the Increase Production Efficiency and Meat Quality of Native Beef and Buffalo Research Group; Research and Graduate Studies, Khon Kaen University (KKU).

Institutional Review Board Statement: The study was conducted under approval procedure no. AENPU A2/2560 of animal Ethics and Care issue by Nakhon Phanom University.

Informed Consent Statement: Not applicable.

Data Availability Statement: Not applicable.

Acknowledgments: Thanks are extended to the Tropical Feed Resources Research and Development Center (TROFREC), Department of Animal Science, Faculty of Agriculture, Khon Kaen University, Khon Kaen, Thailand, for their support with the use of their facilities.

Conflicts of Interest: We declare that no conflict of interest exists among the authors.

\section{References}

1. Elghandour, M.M.Y.; Khusro, A.; Adegbeye, M.J.; Tan, Z.; Abu Hafsa, S.H.; Greiner, R.; Ugbogu, E.A.; Anele, U.Y.; Salem, A.Z.M. Dynamic role of single-celled fungi in ruminal microbial ecology and activities. J. Appl. Microbiol. 2020, 128, 950-965. [CrossRef]

2. Faccio-Demarco, C.; Mumbach, T.; Oliveira-de-Freitas, V.; Fraga e Silva-Raimondo, R.; Medeiros-Gonçalves, F.; Nunes-Corrêa, M.; Burkert-Del Pino, F.A.; Mendonça-Nunes-Ribeiro Filho, H.; Cassal-Brauner, C. Effect of yeast products supplementation during transition period on metabolic profile and milk production in dairy cows. Trop. Anim. Health Prod. 2019, 51, 2193-2201. [CrossRef]

3. Chaucheyras-Durand, F.; Ameilbonne, A.; Bichat, A.; Mosoni, P.; Ossa, F.; Forano, E. Live yeasts enhance fibre degradation in the cow rumen through an increase in plant substrate colonization by fibrolytic bacteria and fungi. J. Appl. Microbiol. 2016, 120, 560-570. [CrossRef] [PubMed]

4. Desnoyers, M.; Giger-Reverdin, S.; Bertin, G.; Duvaux-Ponter, C.; Sauvant, D. Meta-analysis of the influence of Saccharomyces cerevisiae supplementation on ruminal parameters and milk production of ruminants. J. Dairy Sci. 2009, 92, 1620-1632. [CrossRef]

5. Cagle, C.M.; Fonseca, M.A.; Callaway, T.R.; Runyan, C.A.; Cravey, M.D.; Tedeschi, L.O. Evaluation of the effects of live yeast on rumen parameters and in situ digestibility of dry matter and neutral detergent fiber in beef cattle fed growing and finishing diets. Appl. Anim. Sci. 2020, 36, 36-47. [CrossRef]

6. Crossland, W.L.; Cagle, C.M.; Sawyer, J.E.; Callaway, T.R.; Tedeschi, L.O. Evaluation of active dried yeast in the diets of feedlot steers. II. Effects on rumen pH and liver health of feedlot steers. J. Anim. Sci. 2019, 97, 1347-1363. [CrossRef]

7. Sousa, D.O.; Oliveira, C.A.; Velasquez, A.V.; Souza, J.M.; Chevaux, E.; Mari, L.J.; Silva, L.F.P. Live yeast supplementation improves rumen fibre degradation in cattle grazing tropical pastures throughout the year. Anim. Feed Sci. Technol. 2018, 236, 149-158. [CrossRef]

8. Opsi, F.; Fortina, R.; Tassone, S.; Bodas, R.; López, S. Effects of inactivated and live cells of Saccharomyces cerevisiae on in vitro ruminal fermentation of diets with different forage:concentrate ratio. J. Agric. Sci. 2012, 150, 271-283. [CrossRef]

9. Pinloche, E.; McEwan, N.; Marden, J.P.; Bayourthe, C.; Auclair, E.; Newbold, C.J. The Effects of a probiotic yeast on the bacterial diversity and population structure in the rumen of cattle. PLoS ONE 2013, 8, e67824. [CrossRef]

10. Sartori, E.D.; Canozzi, M.E.A.; Zago, D.; Prates, Ê.R.; Velho, J.P.; Barcellos, J.O.J. The Effect of live yeast supplementation on beef cattle performance: A systematic review and meta-analysis. J. Agric. Sci. 2017, 9, 21. [CrossRef]

11. Phesatcha, K.; Phesatcha, B.; Wanapat, M.; Cherdthong, A. Roughage to concentrate ratio and Saccharomyces cerevisiae inclusion could modulate feed digestion and in vitro ruminal fermentation. Vet. Sci. 2020, 7, 151. [CrossRef]

12. Association of Official Analytical Chemists (AOAC). Official Methods of Analysis, 19th ed.; AOAC International: Gaithersburg, MD, USA, 2012.

13. Van Soest, P.J.; Robertson, J.B.; Lewis, B.A. Methods for dietary fiber neutral detergent fiber, and nonstarch polysaccharides in relation to animal nutrition. J. Dairy Sci. 1991, 74, 3583-3597. [CrossRef]

14. Van Keulen, J.Y.; Young, B.A. Evaluation of acid-insoluble ash as a natural marker in ruminant digestibility studies. J. Anim. Sci. 1977, 44, 282-287. [CrossRef]

15. Moss, A.R.; Jouany, J.P.; Newbold, J. Methane production by ruminants: Its contribution to global warming. Anim. Res. 2000, 49, 231-253. [CrossRef]

16. Galyean, M. Laboratory Procedure in Animal Nutrition Research; Department of Animal and Range Sciences, New Mexico State University: Las Cruces, NM, USA, 1989; Volume 188. 
17. Stevenson, D.M.; Weimer, P.J. Dominance of Prevotella and low abundance of classical ruminal bacterial species in the bovine rumen revealed by relative quantification real-time PCR. Appl. Microbiol. Biotechnol. 2007, 75, 165-174. [CrossRef]

18. Koike, S.; Kobayashi, Y. Development and use of competitive PCR assays for the rumen cellulolytic bacteria: Fibrobacter succinogenes, Ruminococcus albus and Ruminococcus flavefaciens. FEMS Microbiol. Lett. 2001, 204, 361-366. [CrossRef]

19. Tajima, K.; Aminov, R.I.; Nagamine, T.; Matsui, H.; Nakamura, M.; Benno, Y. Diet-dependent shifts in the bacterial population of the rumen revealed with real-time PCR. Appl. Environ. Microbiol. 2001, 67, 2766-2774. [CrossRef]

20. Denman, S.E.; Tomkins, N.W.; McSweeney, C.S. Quantitation and diversity analysis of ruminal methanogenic populations in response to the antimethanogenic compound bromochloromethane. FEMS Microbiol. Ecol. 2007, 62, 313-322. [CrossRef]

21. Crocker, C.L. Rapid determination of urea nitrogen in serum or plasma without deproteinization. Am. J. Med. Technol. 1967, 33, 361-365.

22. SAS (Statistical Analysis System). User's Guide: Statistic, 9.3th ed.; SAS Inst. Inc.: Cary, NC, USA, 2013.

23. Guedes, C.M.; Gonçalves, D.; Rodrigues, M.A.M.; Dias-da-Silva, A. Effects of a Saccharomyces cerevisiae yeast on ruminal fermentation and fibre degradation of maize silages in cows. Anim. Feed Sci. Technol. 2008, 145, 27-40. [CrossRef]

24. Mir, Z.; Mir, P.S. Effect of the addition of live yeast (Saccharomyces cerevisiae) on growth and carcass quality of steers fed high-forage or high-grain diets and on feed digestibility and in situ degradability. J. Anim. Sci. 1994, 72, 537-545. [CrossRef]

25. dos Santos Monnerat, J.P.; Paulino, P.V.R.; Detmann, E.; Valadares Filho, S.C.; Valadares, R.D.F.; Duarte, M.S. Effects of Saccharomyces cerevisiae and monensin on digestion, ruminal parameters, and balance of nitrogenous compounds of beef cattle fed diets with different starch concentrations. Trop. Anim. Health Prod. 2013, 45, 1251-1257. [CrossRef] [PubMed]

26. Ghasemi, E.; Khorvash, M.; Nikkhah, A. Effect of forage sources and Saccharomyces cerevisiae (Sc47) on ruminal fermentation parameters. S. Afr. J. Anim. Sci. 2012, 42, 164-168. [CrossRef]

27. Wanapat, M.; Pimpa, O. Effect of ruminal $\mathrm{NH}_{3}-\mathrm{N}$ levels on ruminal fermentation, purine derivatives, digestibility and rice straw intake in swamp buffaloes. Asian-Australas. J. Anim. Sci. 1999, 12, 904-907. [CrossRef]

28. Li, Y.; Shen, Y.; Niu, J.; Guo, Y.; Pauline, M.; Zhao, X.; Li, Q.; Cao, Y.; Bi, C.; Zhang, X.; et al. Effect of active dry yeast on lactation performance, methane production, and ruminal fermentation patterns in early-lactating Holstein cows. J. Dairy Sci. 2021, 104, 381-390. [CrossRef]

29. Jiang, Y.; Ogunade, I.M.; Qi, S.; Hackmann, T.J.; Staples, C.R.; Adesogan, A.T. Effects of the dose and viability of Saccharomyces cerevisiae. 1. Diversity of ruminal microbes as analyzed by Illumina MiSeq sequencing and quantitative PCR. J. Dairy Sci. 2017, 100, 325-342. [CrossRef]

30. Xiao, J.X.; Alugongo, G.M.; Chung, R.; Dong, S.Z.; Li, S.L.; Yoon, I.; Wu, Z.H.; Cao, Z.J. Effects of Saccharomyces cerevisiae fermentation products on dairy calves: Ruminal fermentation, gastrointestinal morphology, and microbial community. J. Dairy Sci. 2016, 99, 5401-5412. [CrossRef] [PubMed]

31. McAllister, T.A.; Beauchemin, K.A.; Alazzeh, A.Y.; Baah, J.; Teather, R.M.; Stanford, K. Review: The use of direct fed microbials to mitigate pathogens and enhance production in cattle. Can. J. Anim. Sci. 2011, 91, 193-211. [CrossRef]

32. Dawson, K.A.; Hopkins, D.M. Differential effects of live yeast on the cellulolytic activities of anaerobic ruminal bacteria. J. Anim. Sci. 1991, 69 (Suppl. 1), 531.

33. Patra, A.K. The use of live yeast products as microbial feed additives in ruminant nutrition. Asian. J. Anim. Vet. Adv. 2012, 7, 366-375. [CrossRef]

34. Wang, Z.; He, Z.; Beauchemin, K.A.; Tang, S.; Zhou, C.; Han, X.; Wang, M.; Kang, J.; Odongo, N.E.; Tan, Z. Evaluation of different yeast species for improving in vitro fermentation of cereal straws. Asian-Australas. J. Anim. Sci. 2016, 29, 230-240. [CrossRef]

35. Munoz, C.; Wills, D.A.; Yan, T. Effects of dietary active dried yeast (Saccharomyces cerevisiae) supply at two levels of concentrate on energy and nitrogen utilisation and methane emissions of lactating dairy cows. Anim. Prod. Sci. 2017, 57, 656-664. [CrossRef]

36. Bayat, A.R.; Kairenius, P.; Stefański, T.; Leskinen, H.; Comtet-Marre, S.; Forano, E.; Chaucheyras-Durand, F.; Shingfield, K.J. Effect of camelina oil or live yeasts (Saccharomyces cerevisiae) on ruminal methane production, rumen fermentation, and milk fatty acid composition in lactating cows fed grass silage diets. J. Dairy Sci. 2015, 98, 3166-3181. [CrossRef] [PubMed]

37. Darabighane, B.; Salem, A.Z.M.; Aghjehgheshlagh, F.M.; Mahdavi, A.; Zarei, A.; Elghandour, M.M.Y.; Lopez, S. Environmental efficiency of Saccharomyces cerevisiae on methane production in dairy and beef cattle via a meta-analysis. Environ. Sci. Pollut. Res. 2018, 26, 3651-3658. [CrossRef] [PubMed]

38. Zhu, W.; Wei, Z.; Xu, N.; Yang, F.; Yoon, I.; Chung, Y.; Liu, J.; Wang, J. Effects of Saccharomyces cerevisiae fermentation products on performance and rumen fermentation and microbiota in dairy cows fed a diet containing low quality forage. J. Anim. Sci. Biotechnol. 2017, 8, 36. [CrossRef] [PubMed]

39. Ding, G.; Chang, Y.; Zhao, L.; Zhou, Z.; Ren, L.; Meng, Q. Effect of Saccharomyces cerevisiae on alfalfa nutrient degradation characteristics and rumen microbial populations of steers fed diets with different concentrate-to-forage ratios. J. Anim. Sci. Biotechnol. 2014, 5, 24. [CrossRef]

40. Lu, Q.; Wu, J.; Wang, M.; Zhou, C.; Han, X.; Odongo, E.N.; Tan, Z.; Tang, S. Effects of dietary addition of cellulase and a Sacharomyces cerevisiae fermentation product on nutrient digestibility, rumen fermentation and enteric methane emissions in growing goats. Arch. Anim. Nutr. 2016, 70, 224-238. [CrossRef] [PubMed] 